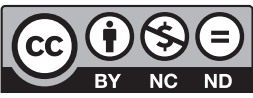

Estudos Teológicos foi licenciado com uma Licença Creative Commons Atribuição - NãoComercial - SemDerivados 3.0 Não Adaptada

http://dx.doi.org/10.22351/et.v58i2.3014

\title{
O ACOLHIMENTO DA GRAVIDEZ EM COMUNIDADE CRISTÃ: OS DESAFIOS DA RESPONSABILIDADE PARENTAL ${ }^{1}$
}

\author{
The welcoming of pregnancy in a Christian community: \\ challenges of parental responsibility
}

Mário Antônio Sanches ${ }^{2}$
Luiz Fernando de Lima

Resumo: Este artigo se situa no contexto do planejamento familiar com o objetivo principal de identificar o quanto agentes de pastoral de uma comunidade cristã acolheram a gravidez do primeiro filho. Método: Este trabalho é fruto de uma pesquisa bibliográfica e de campo realizada com 278 agentes de pastoral da Diocese de Jacarezinho, estado do Paraná, Sul do Brasil. A pesquisa foi efetivada a partir da aplicação do Instrumento de Pesquisa: Planejamento de Parentalidade no Contexto da Bioética. A amostra estudada apresentou um perfil predominantemente feminino, com idade acima de 46 anos, com menos de três filhos, de casados e com escolaridade de ensino médio completo ou acima. Resultado: Este artigo explora a resposta dos participantes da pesquisa à indagação: "Qual foi a sua reação ao anúncio da gravidez do primeiro filho?" De acordo com as possibilidades de respostas apresentadas, o resultado foi o seguinte: revolta $0,5 \%$, preocupação $13,1 \%$, surpresa $4,7 \%$, aceitação $7,9 \%$ e alegria $64,8 \%$. Esses dados foram cruzados e explorados na perspectiva de gênero, idade da primeira gravidez, estado civil, situação de empregabilidade e número de filhos. Conclusão: A pesquisa revela pontos de convergência entre o pensamento da liderança religiosa e a prática de agentes de pastoral relacionados com o planejamento familiar, mas também demonstra tensões e dificuldades.

Palavras-chave: Planejamento familiar. Acolhimento da gravidez. Agentes de pastoral. Comunidade brasileira.

\footnotetext{
1 O artigo foi recebido em 13 de maio de 2017 e aprovado em 03 de junho de 2018 com base nas avaliações dos pareceristas ad hoc.

2 Doutor em Teologia com pós-doutorado em Bioética. Professor titular da Pontifícia Universidade Católica do Paraná, Curitiba, Paraná, Brasil. Contato: m.sanches@pucpr.br

3 Doutor em Teologia pela PUCPR. Presbítero da Diocese de Jacarezinho. Professor do Seminário de Teologia Divino Mestre de Jacarezinho e do Mosteiro da Ressurreição em Ponta Grossa (PR). Jacarezinho, Paraná, Brasil. Contato: padreluizfernandolima@gmail.com
} 
Abstract: This article is situated in the context of family planning with the objective of identifying how much pastoral agents of a Christian community welcomed the pregnancy of the first child. Method: This work is the fruit of a bibliographical and field research held with 278 pastoral agents of the Diocese of Jacarezinho, Paraná State, southern Brazil. The research was carried out from the application of questionnaire: Parenting planning in the context of bioethics. The sample studied showed a profile predominantly female, over the age of 46 years, with fewer than three children, married and with complete high school education or above. Result: This article explores the response to the question: 'What was your reaction to the announcement of the pregnancy of the first child?' According to the possibilities of answers submitted the result was as follows: $0.5 \%$ revolt, $13.1 \%$ concern, surprise $4.7 \%, 7.9 \%$ acceptance and joy $64.8 \%$. These data were crossed and explored from the perspective of gender, age of first pregnancy, marital status, employment status and number of children. Conclusion: The research reveals convergences between the thinking of the Church's leaders and the practice of pastoral agents related to family planning, but also demonstrates tensions and difficulties.

Keywords: Family planning. Welcoming pregnancy. Pastoral agentes. Brazilian community.

\section{Introdução}

O planejamento familiar no âmbito das comunidades cristãs apresenta-se de modo controverso, pois não há uma abordagem única entre as igrejas cristãs sobre o assunto, nem mesmo uma sintonia plena no interior de uma mesma comunidade religiosa. Por exemplo, na Igreja Católica há desencontros e dissonâncias, principalmente no tocante ao modo como o magistério da igreja se pronuncia e o modo como os fiéis leigos exercem o planejamento familiar. Percebe-se conflito nas consciências de alguns fiéis e desconhecimento em outros. Há ainda aqueles que pensam ser a Igreja Católica totalmente contrária ao planejamento familiar devido à discussão sobre métodos contraceptivos naturais e artificiais. À parte do posicionamento sobre métodos contraceptivos, podemos identificar elementos do planejamento familiar - acolhimento dos filhos e parentalidade responsável -, ao redor dos quais é possível um diálogo mais produtivo entre as lideranças religiosas e os fiéis e mesmo entre diferentes igrejas. De qualquer modo a atual experiência de serem pais e mães constantemente desafia as posições religiosas tidas como "oficiais" sobre o assunto.

Portanto este artigo se situa no cenário do planejamento familiar com o objetivo principal de identificar o quanto agentes de pastoral, em um determinado contexto, acolheram a gravidez. $\mathrm{O}$ artigo aborda o momento do anúncio da gravidez buscando identificar como os agentes de pastoral, comprometidos com a ação de uma determinada igreja, a católica, tem planejado e acolhido seus filhos. Como a temática é bastante ampla, este artigo restringe-se a apresentar brevemente o posicionamento da Igreja Católica a respeito do planejamento familiar, a relação entre planejamento familiar e amor conjugal e a desejável parentalidade responsável. Para manter o 
objetivo do artigo serão apresentados os dados de pesquisa de campo após a revisão teórica dos temas acima abordados.

\section{Metodologia}

Além da revisão bibliográfica, este trabalho é fruto de uma pesquisa de campo realizada com agentes de pastoral que atuam no território da Diocese Católica de Jacarezinho, estado do Paraná, Sul do Brasil. A pesquisa foi efetivada a partir da aplicação do Instrumento de Pesquisa: Planejamento de Parentalidade no Contexto da Bioéti$\mathrm{ca}^{4}$, que consta de 53 questões relacionadas com planejamento familiar.

A pesquisa ${ }^{5}$ foi realizada entre as lideranças de 46 paróquias da diocese católica de Jacarezinho, situada no interior do estado do Paraná. De acordo com a análise estatística inicial, o total de agentes entrevistados foi de 278 , uma amostra aceitável considerando um nível de confiança de $95 \%$ e margem de erro de $5 \%$, visto que há uma estimativa de mil agentes de pastoral com o perfil desejado. De fato, o total de agentes entrevistados foi de 310, sendo 278 com respostas completas. Foram incluídos entre os sujeitos a responder o questionário os agentes de pastoral de todos os gêneros, com mais de três anos de atuação, maiores de 18 anos e pais de pelo menos um filho. Foram excluídas da pesquisa as pessoas que estavam vivenciando uma situação de gravidez.

Com o objetivo de zelar pela privacidade dos agentes de pastoral, o questionário foi entregue em envelopes aos participantes da pesquisa em momentos de reuniões nas comunidades, após uma detalhada explicação do objetivo de toda esta pesquisa. Os participantes tiveram tempo hábil para responder e depois os envelopes foram recolhidos, sem identificação.

\section{Tabela 1 - Perfil geral dos entrevistados}

Perfil geral dos entrevistados: por gênero, idade atual, número de filhos, estado civil e escolaridade.

\begin{tabular}{lcc}
\multicolumn{1}{c}{ Gênero } & Percentagem & $\boldsymbol{N}^{\boldsymbol{o}}$ de entrevistados \\
\hline Masculino & $20,5 \%$ & 57 \\
\hline Feminino & $78,4 \%$ & 218 \\
\hline \multicolumn{1}{c}{ Idade atual } & & $\boldsymbol{N}^{\boldsymbol{o}}$ de entrevistados \\
\hline Entre 18 e 25 anos & $2,2 \%$ & 06 \\
\hline Entre 26 e 35 anos & $20,9 \%$ & 58 \\
\hline Entre 36 e 45 anos & $29,1 \%$ & 81 \\
\hline Entre 46 e 60 anos & $36,0 \%$ & 100 \\
\hline Acima de 60 anos & $9,7 \%$ & 27 \\
\hline
\end{tabular}

4 SANCHES, Mário Antônio; et al. Planejamento da Parentalidade no contexto da bioética: busca de uma nova abordagem para pesquisa. Ed. Universitária Champagnat, PUCPR. Curitiba, PR, 2015.

5 Em se tratando de pesquisa com seres humanos, no sentido de manuseio de informações, o projeto foi antes submetido e aprovado pelo Comitê de Ética em Pesquisa da PUCPR, com parecer de número 409.841 na data de 25/09/2013. 


\begin{tabular}{lcc}
\hline \multicolumn{1}{c}{ Número de filhos } & Percentagem & $\boldsymbol{N}^{\boldsymbol{o}}$ de entrevistados \\
\hline 1 filho & $29,9 \%$ & 83 \\
\hline 2 filhos & $24,8 \%$ & 69 \\
\hline 3 filhos & $31,7 \%$ & 88 \\
\hline 4 ou mais & $12,6 \%$ & 35 \\
\hline
\end{tabular}

Fonte: Os autores, 2014.

O perfil geral dos entrevistados é apresentado na Tabela 1, construída a partir das variáveis de gênero, idade e número de filhos. Como se vê, a amostra estudada apresentou um perfil predominantemente feminino, com idade acima de 46 anos, com menos de três filhos. A questão que interpela sobre a idade atual dos entrevistados revela que aproximadamente a metade deles $(45,7 \%)$ tem idade superior a 46 anos. Esse dado necessita ser levado em conta nesta pesquisa, pois quando se indaga a respeito do nascimento do primeiro filho, é preciso estar ciente que se investiga uma realidade ocorrida em média há 25 anos para essa parcela dos entrevistados. Outro dado relevante é que a grande maioria dos que indicaram "4 ou mais filhos" está situada em faixa etária acima de 46 anos, o que corresponde à mudança de taxa de natalidade ocorrida no Brasil nas últimas décadas.

\section{O planejamento familiar na Igreja Católica}

O ensinamento da Igreja Católica, na atualidade, apoia e incentiva o planejamento familiar, desde que realizado a partir de certos critérios. Por isso vamos explicitar essa compreensão e trazer os dados da pesquisa que apontam para o quanto os agentes de pastoral vivenciam essa realidade em suas famílias.

\section{Abertura ao planejamento familiar na igreja}

No século XX, a Igreja Católica abre-se lentamente ao planejamento familiar, como aponta o seu Catecismo:

Um aspecto particular desta responsabilidade [gerar filhos no matrimônio] diz respeito à regulação da procriação. Por razões justas, os esposos podem querer espaçar os nascimentos de seus filhos. Cabe-lhes verificar que seu desejo não provém do egoísmo, mas está de acordo com a justa generosidade de uma paternidade responsável. Além disso, regularão seu comportamento segundo os critérios objetivos da moral ${ }^{6}$.

O planejamento familiar passa a ser aceito pela Igreja Católica a partir da década de 1950, quando Pio XII dá uma aprovação positiva a respeito do planejamento, com ressalva sobre os métodos contraceptivos a serem utilizados. Assim destaca-se que o amor é entendido como essencialmente fecundo. Amor esse que tende a "pro-

${ }^{6}$ CATECISMO DA IGREJA CATÓLICA. Petrópolis: Vozes; São Paulo: Loyola, 2000. n. 2.368. 
criar" material e espiritualmente, de modo que essa fecundidade é pessoal e não automática e cega. De fato, na Gaudium et $\operatorname{Spes}^{7}$ se pode ler: "O matrimônio não foi instituído apenas para o fim procriativo [...] mas para que o amor recíproco cresça e amadureça"s. Esse é o filão pelo qual se deve entender o planejamento familiar nos documentos do magistério católico: o amor conjugal. Como consequência dessa personalização do amor, cada vez mais se tomou consciência de que a fecundidade tem que ser verdadeiramente responsável, já que "toda criança que vem ao mundo tem o direito a ter um lugar, a ser alimentada e a ser educada convenientemente"

Momento marcante da posição da igreja se deu com a Humanae Vitae, carta encíclica escrita em 1968, que assume a concepção personalista do Vaticano II ao considerar o amor conjugal fecundo como valor central do matrimônio. Essa encíclica assume a teologia do Vaticano II com respeito ao planejamento familiar responsável e também a posição de Pio XII quanto aos métodos, evidenciando que "para o casal cristão a regulação dos nascimentos não é um simples não querer ter filhos, mas a aceitação consciente deles como fruto do amor; não só no processo da concepção, mas também no seu desenvolvimento até a idade adulta" ${ }^{10}$. Além de todas as polêmicas e posicionamentos diversos surgidos à época de sua publicação, devido à não aceitação de muitos métodos contraceptivos, uma leitura atenta desse documento de Paulo VI deixa transparecer uma rica teologia do amor conjugal. A posição da Igreja Católica sobre os métodos contraceptivos pode mudar diante da face dinâmica da teologia e seu desenvolvimento. Persistirá, no entanto, a visão do amor conjugal como unidade de dois, ou seja, um amor que é livre e se empenha na direção do bem do outro, porque vê ali seu próprio bem e em vista dessa razão permanece fiel. Em outros termos, a mudança na compreensão dos métodos contraceptivos não obnubilará o entendimento do amor conjugal como:

- um amor eminentemente humano que integra sabiamente eros e ágape, as expressões do corpo e da alma.

- um amor que vai de uma pessoa para outra pessoa, portanto, um amor interpessoal que une em um só o ato de doação e acolhida recíprocas.

- um amor que cria uma amizade específica, a amizade conjugal ${ }^{11}$.

Moser apresenta uma reflexão bastante interessante quanto ao planejamento familiar e fecundidade em torno da Humanae Vitae:

CONCÍLIO VATICANO II, Constituição Pastoral Gaudium et Spes sobre a Igreja no mundo atual, n. 50.

8 Um livro interessante sobre esse tema é: WOJTYLA, Karol. Amor e Responsabilidade: estudo ético. São Paulo: Loyola, 1982.

9 HORTELANO, Antonio. El amor y la familia en las nuevas perspectivas cristianas. Salamanca: Sígueme, 1974. p. 187.

${ }^{10}$ MOSER, Antônio. A paternidade responsável face a uma mentalidade contraceptiva. 3. ed. Petrópolis: Vozes, 1982. p. 29.

${ }^{11}$ BOTERO, Sílvio. O amor conjugal: fundamento do casal humano. Aparecida: Santuário, 2001. p. 123. 
No que se refere especificamente ao planejamento familiar, foram sendo mais bem delineadas as exigências evangélicas, no sentido de amor profundo, abertura à vida e as motivações de fundo. Assim, não poucos teólogos passaram a sustentar que, excluídos os métodos radicais da esterilização e, sobretudo do aborto, a questão moral apontava menos para os métodos e mais para as atitudes. $\mathrm{O}$ fato de um casal seguir rigorosamente os métodos naturais não significaria forçosamente fidelidade à Igreja, e vice-versa. A responsabilidade no sentido ético do termo tem muito mais a ver com reflexão consciente, que a um só tempo busca sintonia com a inspiração da Igreja e a superação de todo tipo de egoísmo ${ }^{12}$.

Como se nota, a partir da Humanae Vitae o planejamento familiar remete a uma concepção entranhada do mistério da vida como dom capital de Deus ao ser humano.

\section{Acolhida aos filhos: dados da pesquisa de campo}

A fim de relacionar as reflexões acima sobre a realidade do planejamento familiar na Igreja Católica com a prática dos fiéis, trazemos dados da pesquisa descrita acima. A indagação central que perpassa este artigo está relacionada ao acolhimento do filho como fruto do amor, por isso a questão que será exaustivamente trabalhada se refere a uma das 53 questões do Instrumento de Pesquisa: "Qual foi a sua reação ao anúncio da gravidez do primeiro filho?’. Seguem na Tabela 2 as respostas gerais a essa questão, tendo em conta que aos participantes da pesquisa foram apresentadas as seguintes possibilidades de respostas: revolta, preocupação, surpresa, aceitação, alegria.

\section{Tabela 2 - Anúncio da primeira gravidez}

\begin{tabular}{c|c|c|c|c}
\hline \multicolumn{5}{c}{ Dados relacionados à reação ao anúncio da gravidez do primeiro filho } \\
\hline Revolta & Preocupação & Surpresa & Aceitação & Alegria \\
\hline $0,5 \%$ & $13,1 \%$ & $4,7 \%$ & $7,9 \%$ & $64,8 \%$ \\
\hline
\end{tabular}

Fonte: Os autores, 2014.

Ter filhos tem se tornado a cada dia mais exigente e os dados advindos da queda da taxa de natalidade no Brasil apontam para esse fato. ${ }^{13}$ No entanto, em se tratando de uma gravidez - sobretudo da gravidez do primeiro filho, parece que o clima no qual esse anúncio se dá é preferentemente a alegria, uma vez que 64,8\% dos entrevistados

12 MOSER, Antônio. Planejamento familiar atual na Igreja Católica: do ruído estrondoso a um silêncio perturbador. In: SANCHES, M. A. (Org.). Bioética e planejamento familiar: perspectivas e escolhas. Petrópolis: Vozes, 2014. p. 62.

13 A taxa de fecundidade no Brasil apresentou uma considerável queda de 20,1\% entre 2000 e 2010. Em 2000, a média de filhos era de 2,38 por mulher; em 2010, a média não passou de 1,90 por mulher. Em cinquenta anos, as brasileiras tiveram 4,4 filhos a menos, uma vez que em 1960 a média de filhos por mulher era de 6,3. Esses dados são provenientes de: IBGE. Pesquisa Nacional por amostra de Domicílios (Pnad) 2006. Disponível em: <http://www.ibge.gov.br/home/presidencia/noticias>. Acesso em: 18 mar. 2014. 
assinalaram essa opção como resposta. Esse dado relevante mostra, assim, a sintonia dos agentes com os ensinamentos da Igreja Católica, que aponta para esse necessário de acolhimento dos filhos como fruto do amor conjugal.

Essa expressiva percentagem apontada acima não esconde a realidade presente em muitas gravidezes. O quadro desenhado mostra que 7,9\% reagem com "aceitação" à gravidez primigênia; outros 4,7\% demonstraram "surpresa" com essa notícia; e $13,1 \%$ acolheu esse anúncio com "preocupação", ao passo que $0,5 \%$ recebeu a primeira gravidez numa esfera de "revolta". Somando as respostas relacionadas com "revolta", "preocupação" e "surpresa", temos 18,3\%, o que indica claramente uma dissonância entre a atitude proposta pela Igreja Católica e a realidade desses agentes.

A pesquisa não oferece informações suficientes para uma análise dos porquês dessas últimas realidades apontadas. Todavia, podem-se supor algumas situações que eventualmente se colocam como causas dessas realidades. Em se tratando de Brasil, onde parte da gravidez se dá na adolescência, pode-se sugerir a baixa faixa etária como um despreparo afetivo, emocional, financeiro, por exemplo, levando uma nova vida a ser acolhida entre revolta, preocupação, surpresa e aceitação. De fato, uma pesquisa realizada no Brasil por conta do $2^{\circ}$ Levantamento Nacional de Álcool e Drogas, realizado pela Universidade Federal de São Paulo, mostrou que um terço dos jovens entre 14 e 25 anos nunca usa camisinha em suas relações sexuais e $32 \%$ das mulheres com até 20 anos de idade já engravidaram pelo menos uma vez. ${ }^{14}$

A Tabela 3 apresenta os dados da reação no anúncio da gravidez do primeiro filho em relação a gênero. Ainda que seja uma diferença muito pequena, chama a atenção o fato de uma percentagem maior de homens do que de mulheres ter recebido a notícia da chegada do primeiro filho num clima de alegria. Talvez esses números evidenciem a consciência mais aguçada das mulheres no que diz respeito à responsabilidade que envolve a gestação e o cuidado de um filho ao longo da vida. A porcentagem mais alta de mulheres que acolheram o anúncio da gravidez do primeiro filho com preocupação e surpresa revela o descompromisso masculino frente ao assunto, e o fato de, segundo Ricci ${ }^{15}, 40 \%$ dos pais adolescentes abandonarem as parceiras antes do nascimento do filho.

\section{Tabela 3 - Anúncio da primeira gravidez e gênero}

Reação ao anúncio da primeira gravidez cruzado com os dados sobre gênero dos participantes da pesquisa

\begin{tabular}{lccccc}
\hline & Revolta & Preocupação & Surpresa & Aceitação & Alegria \\
\hline Feminino & $0 \%$ & $16,1 \%$ & $5,0 \%$ & $7,8 \%$ & $69,3 \%$ \\
\hline Masculino & $1,8 \%$ & $10,5 \%$ & $3,5 \%$ & $7,0 \%$ & $71,9 \%$ \\
\hline
\end{tabular}

Fonte: Os autores, 2014.

14 Esses dados foram publicados no Jornal “O Estado de São Paulo” no dia 27 de março de 2014, p. A19.

15 RICCI, Luiz Antônio Lopes. Planejamento familiar à luz da ética teológica. In: SANCHES (Org.), 2014, p. 92. 


\section{Acolher os filhos na perspectiva do amor conjugal}

No pensamento da Igreja Católica, a relação entre planejamento familiar e amor conjugal é fundamental, como já fora introduzido acima. Neste item voltamos ao tema dadas sua relevância e a necessidade de relacionar a questão com a pesquisa de campo.

\section{Relação entre o amor conjugal e acolhimento dos filhos na igreja}

A Igreja Católica entende o planejamento familiar dentro da realidade matrimonial, uma vez que entre dois batizados não pode haver uma união conjugal que não seja considerada matrimônio. ${ }^{16}$ No entender da doutrina católica, o matrimônio é o lugar que torna possível a doação total entre o homem e a mulher com os atos próprios e exclusivos dos esposos, como, por exemplo, a geração de uma nova vida. Compreende-se que "o amor conjugal reúne em si valores humanos e divinos que levam os esposos ao autêntico, livre e mútuo dom de si mesmos" ${ }^{17}$. O Catecismo da Igreja Católica identifica bem essa relação entre matrimônio e planejamento familiar, apresentando os pais como cooperadores do amor de Deus criador e também como seus intérpretes.

Chamados a dar vida, os esposos participam do poder criador e da paternidade de Deus. "Os cônjuges sabem que, no ofício de transmitir a vida e de serem educadores - o qual deve ser considerado como missão própria deles -, são cooperadores do amor de Deus criador e como seus intérpretes. Por isso desempenharão seu múnus com responsabilidade cristã e humana". ${ }^{18}$

Essa posição é reflexo do Vaticano II, pois segundo a Gaudium et Spes, "o Matrimônio e o amor conjugal destinam-se por sua própria natureza à geração e educação da prole. Os filhos são, sem dúvida, o maior dom do Matrimônio e contribuem muito para o bem dos próprios pais" ${ }^{\prime 19}$. O amor conjugal apresenta-se, portanto, como ato eminentemente humano, dirigido de pessoa a pessoa com um sentimento e uma ação que nasce da vontade livre. Na década de 1960, o teólogo Edward Schillebeeckx subtitulou sua célebre obra sobre o matrimônio indicando-a como "realidade terrena e mistério de salvação" 20 . A análise desses dois aspectos complementares parece dar uma satisfatória noção da realidade do matrimônio no entendimento eclesial.

${ }^{16}$ Cf. CÓDIGO DE DIREITO CANÔNICO, cânon 1055 § 2.

17 GHIRLANDA, Gianfranco. O Direito na Igreja: Mistério de Comunhão-compêndio de Direito Eclesial. Aparecida: Santuário, 2003. p. 375.

${ }_{18}$ CATECISMO DA IGREJA CATÓLICA, n. 2.367.

${ }^{19}$ CONCÍLIO VATICANO II. Constituição Pastoral Gaudium et Spes. 28. ed. Petrópolis: Vozes, 2000. n. 50.

${ }^{20}$ Cf. SCHILLEBEECKX, Edward. El Matrimonio: realidad terrena y misterio de salvación. Salamanca: Sígueme, 1968. 


\section{Estado civil e acolhimento da gravidez: dados da pesquisa de campo}

Como se percebe, a compreensão personalista do matrimônio é o fundamento da ética conjugal e, consequentemente, do planejamento familiar que radica na experiência do amor entre os cônjuges. Devido a esta ênfase anotada nas igrejas cristãs em situar os filhos no contexto do matrimônio -, é interessante observar o modo como essa realidade acontece na prática dos cristãos, tendo em conta a pesquisa realizada com agentes de pastoral.

No instrumento da pesquisa, a variável "Estado civil na gravidez do primeiro filho" apresenta as sete seguintes possibilidades que apresentamos aqui com seus resultados: solteiro, 50 respostas $(18 \%)$; casado, $189(68 \%)$; divorciado, $5(1,8 \%)$; viúvo, 2 (0,7\%); união estável, 23 (8,3\%); separado judicialmente, 4 (1,4\%); não respondeu, $5(1,8 \%)$. A Tabela 5 apresenta o resultado das categorias com relevância estatística cruzando esses resultados com a "reação ao anúncio da primeira gravidez".

\section{Tabela 4 - Anúncio da primeira gravidez e o estado civil}

\begin{tabular}{|c|c|c|c|c|c|}
\hline \multicolumn{6}{|c|}{$\begin{array}{l}\text { Dados relacionados com reação ao anúncio da gravidez do primeiro filho, cruzados } \\
\text { com dados a respeito do estado civil dos participantes da pesquisa no momento } \\
\text { da gravidez do primeiro filho }\end{array}$} \\
\hline & Revolta & Preocupação & Surpresa & Aceitação & Alegria \\
\hline Solteiro & $0 \%$ & $48 \%$ & $10 \%$ & $10 \%$ & $32 \%$ \\
\hline Casado & $0,5 \%$ & $5,3 \%$ & $4,2 \%$ & $7,9 \%$ & $79,9 \%$ \\
\hline União estável & $0 \%$ & $21,7 \%$ & $0 \%$ & $4,3 \%$ & $65,2 \%$ \\
\hline
\end{tabular}

Fonte: Os autores, 2014.

Os dados são relevantes, pois apontam na direção do pensamento da Igreja Católica que insiste na estabilidade do matrimônio e sua relação com ter filhos. Observa-se que para os $48 \%$ dos "solteiros" que responderam ter recebido com preocupação o anúncio da primeira gravidez, essa percentagem cai para $21,7 \%$ entre as pessoas que indicaram ter uma "união estável", e é reduzida para 5,3\% entre as pessoas que indicaram estar "casadas" no momento da primeira gravidez. Coerentemente o movimento inverso é percebido, pois 79,9\% dos "casados" no momento da gravidez do primeiro filho revelam ter reagido à gravidez com "alegria", sendo que essa percentagem cai para $65 \%$ entre os que indicaram "união estável" 21 e somente $32 \%$ dos que se encontravam "solteiros' no momento da gravidez receberam esse anúncio com alegria. Os que se encontravam numa situação de viuvez, separação ou divórcio não foram considerados por se tratar de um inexpressivo número dentro do montante analisado.

A situação apontada na Tabela 4 aponta assim para o fato de que a estabilidade no matrimônio continua sendo uma segurança razoável para aqueles que enfrentam a

${ }^{21}$ Para compreensão mais aprofundada do conceito de união estável: cf. CONSELHO PONTIFÍCIO PARA A FAMÍLIA. Família, Matrimônio e “Uniões de Fato”. 3. ed. São Paulo: Paulinas, 2004. 
empreitada de gerar um filho. Solteiros e os que vivem em união estável lidam com o fato de que o seu vínculo nem sempre oferece uma tutela legal ou religiosa, o que pode acarretar em menor disponibilidade para o acolhimento da gravidez. Isso precisa ser melhor compreendido e é notável que $65,2 \%$ dos que vivenciaram a gravidez do primeiro filho em união estável também acolheram com alegria o seu anúncio.

\section{Parentalidade responsável}

A posição da Igreja Católica em prol do planejamento familiar surge do acolhimento de expectativas sociais que apresentam uma preocupação crescente com a reprodução humana, que pode ser melhor compreendida hodiernamente impactada por outros elementos - além dos biológicos -, dentre eles processos psicológicos, sociais e culturais. O que se viu inicialmente foi o surgimento da expressão "paternidade responsável" compreendida como a

reflexão e a decisão altamente ponderada, à base de um ato de amor autêntico, tomada depois de um diálogo entre ambos os esposos, sobre a oportunidade de ampliar a família ou o dever de espaçar a transmissão da vida de acordo com o bem pessoal das duas partes dialogantes e da adequada educação dos filhos já nascidos ${ }^{22}$.

Passamos assim a analisar o modo como a Igreja Católica fala desse tema e depois vamos analisar os dados da pesquisa sobre responsabilidade no planejamento familiar.

\section{Parentalidade responsável na Igreja Católica}

Para a Igreja Católica, a parentalidade responsável implica assumir os filhos que naturalmente surgem do relacionamento amoroso dos esposos e que o casal possa educar adequadamente. Nessa perspectiva o planejamento familiar não significa necessariamente diminuir o número de filhos simplesmente, mas ter os filhos que se pode assumir com responsabilidade. ${ }^{23}$ Neste contexto, planejamento familiar passa a ser mais aceito do que controle de natalidade, visto que esse termo pode incluir uma redução das taxas de natalidade a qualquer preço. Por certo, muitas vezes o aborto é parte da agenda do planejamento familiar de algumas organizações, o que será visto pela teologia católica, e cristã como um todo, como inadequado: "O aborto é a contradição mais clara contra a paternidade e maternidade responsável, porque é o não mais violento contra a vida humana precisamente depois de haver transmitido esta vida" 24 . Planejamento familiar e amor conjugal andam de mãos dadas. Häring lembra que "o filho nunca pode se tornar objeto de frios cálculos de eficiência. A criança que deve

22 EGUREN, J. A. Paternidad responsable y valores humanos: aportación al diálogo sobre la planificación familiar. Valencia: Edicep, 1976. p. 52.

23 Cf. MOSER, 1982, p. 29.

${ }^{24}$ HÄRING, Bernhard. Paternidad responsable. Madrid: Paulinas, 1971. p. 79. 
receber sua vida por uma superabundância de amor, só pode desabrochar sob o sol do amor conjugal' ${ }^{25}$. Assim a moral cristã, em geral, não determina o número ideal de filhos. Gerar filhos, portanto, não pode ser uma atitude irrefletida e obra do acaso. Häring a considera como uma "responsabilidade assumida com alegria" 26 . Essa responsabilidade, para um cristão, precisa ser levada muito a sério, pois, como indica o cardeal Suenens, gestar uma nova vida é cooperar de modo sublime com o Criador. ${ }^{27}$

\section{Acolhimento da gravidez e responsabilidade social: dados da pesquisa de campo}

O primeiro aspecto a ser analisado é a questão do número de filhos. Dentre os 278 participantes da pesquisa, $83(29,9 \%)$ indicaram ter apenas um filho, $69(23,8 \%)$ afirmaram ter dois filhos, 88 (31,7\%) afirmaram ter três filhos e 35 (12,6\%) participantes indicaram ter quatro ou mais filhos, sendo que três $(1,1 \%)$ não responderam. Neste caso entendemos como muito interessante apresentar os dados relacionados à gravidez do primeiro e do último filho, por isso a Tabela 5 revela a reação ao anúncio da gravidez para essas duas situações.

\section{Tabela 5 - Anúncio da gravidez do primeiro filho e número de filhos}

Dados relacionados com reação ao anúncio da gravidez do primeiro filho cruzados com dados a respeito do número de filhos dos participantes da pesquisa

\begin{tabular}{lccccc}
\hline & Revolta & Preocupação & Surpresa & Aceitação & Alegria \\
\hline & $\begin{array}{c}\text { Primeiro - } \\
\text { último }\end{array}$ & $\begin{array}{c}\text { Primeiro - } \\
\text { último }\end{array}$ & $\begin{array}{c}\text { Primeiro - } \\
\text { último }\end{array}$ & $\begin{array}{c}\text { Primeiro - } \\
\text { último }\end{array}$ & $\begin{array}{c}\text { Primeiro - } \\
\text { último }\end{array}$ \\
\hline 1 filho & $0 \%-0 \%$ & $16,9 \%-0 \%$ & $4,8 \%-0 \%$ & $6 \%-0 \%$ & $68,7 \%-0 \%$ \\
\hline 2 filhos & $0 \%-1,5 \%$ & $10,1 \%-17,6 \%$ & $7,2 \%-11,8 \%$ & $10,1 \%-10,3 \%$ & $69,6 \%-57,4 \%$ \\
\hline 3 filhos & $1,1 \%-1,1 \%$ & $19,3 \%-9,2 \%$ & $3,4 \%-4,6 \%$ & $4,5 \%-6,9 \%$ & $69,3 \%-72,4 \%$ \\
\hline 4 ou + filhos & $0 \%-6,1 \%$ & $5,7 \%-21,2 \%$ & $2,9 \%-6,1 \%$ & $11,4 \%-9,1 \%$ & $80 \%-57,6 \%$ \\
\hline
\end{tabular}

Fonte: Os autores, 2014.

Tendo presente agora o número de filhos e a reação causada pelo anúncio da gravidez do primeiro e do último filho, é digno de nota apontar que independentemente da quantidade de filhos, a reação foi de alegria quando do anúncio das duas gravidezes. Destacando, todavia, que pessoas que indicaram ter quatro filhos ou mais revelaram o índice mais alto $(80 \%)$ de alegria no anúncio da gravidez do primeiro filho e o índice mais baixo $(57,6 \%)$ quando se tratava da gravidez do último filho. Os dados, no entanto, precisam ser cuidadosamente analisados, pois não revela um padrão constante. Por exemplo, o anúncio da gravidez do último filho provoca uma

${ }^{25}$ HÄRING, Bernhard. Matrimônio em nosso tempo. Trad. José Antônio G. da Silva Marques. São Paulo: Herder, 1965. p. 340.

${ }^{26}$ HÄRING, 1965, p. 350.

27 HÄRING, 1965, p. 351. 
reação de menor alegria do que da gravidez do primeiro filho, mas isso para quem teve dois e quatro ou mais, mas não para as pessoas com três filhos. Ou seja, há outras variáveis, além do número de filhos, que podem influenciar nessa reação, que não se podem analisar neste artigo. Um padrão que a tabela revela é que a gravidez do último filho provoca maior reação de surpresa do que a do primeiro filho, o que sugere que o último filho foi menos planejado que o primeiro.

Se, por um lado, o número de filhos não implicou diferença significativa no acolhimento dos filhos, a situação de emprego o faz com clareza. A Tabela 6 revela o quanto o índice econômico pode ser um dos condicionantes de não acolhimento dos filhos.

\section{Tabela 6 - Anúncio da primeira gravidez e a situação de emprego}

Dados relacionados com reação ao anúncio da gravidez do primeiro filho cruzados com dados a respeito da situação de emprego dos participantes da pesquisa

\begin{tabular}{l|r|r|r|r|r} 
& Revolta & Preocupação & Surpresa & Aceitação & Alegria \\
\hline Empregado(a) & $1,1 \%$ & $13,7 \%$ & $5,3 \%$ & $3,2 \%$ & $76,8 \%$ \\
\hline Desempregado(a) & $0 \%$ & $44,4 \%$ & $11,1 \%$ & $11,1 \%$ & $33,3 \%$ \\
\hline Autônomo(a) &, $0 \%$ & $20,8 \%$ & $0 \%$ & $8,3 \%$ & $62,5 \%$ \\
\hline Do lar & $0 \%$ & $7,5 \%$ & $3,8 \%$ & $11,3 \%$ & $75 \%$ \\
\hline Outro &, $0 \%$ & $0 \%$ & $50 \%$ & $50 \%$ & $0 \%$ \\
\hline
\end{tabular}

Fonte: Os autores, 2014.

Como se percebe na Tabela 6, a realidade empregatícia vivida durante o tempo do anúncio da gravidez sugere dados importantes. Mais uma vez, o clima de alegria sobressai em relação às outras opções de resposta, variando num percentual entre $33 \%$ para "desempregado" a 76\% para "empregado". Um dado elevado apresentado por essa tabela, porém compreensível, são os 44,4\% que viviam uma situação de desemprego e acolheram o anúncio da gravidez primigênia com preocupação. Também esse número marcante pode sugerir a compreensão segundo a qual o cuidado para com o filho prescreve um razoável planejamento financeiro estável. Essa realidade de preocupação, outrossim, aparece em percentagens significativas quando se trata daqueles que estavam empregados e que trabalham de forma autônoma. Entre os empregados o clima de preocupação esteve presente em 13,7\% das vezes. Entre os autônomos esse número sobe para 20,8\%. Mesmo possuindo um equilíbrio financeiro, a realidade de um filho ainda preocupa. Neste mundo que gera necessidades desnecessárias a cada novo dia, um filho se apresenta necessitado de todo carinho, atenção, amor, dedicação e de toda possibilidade de crescer em idade, sabedoria e graça (cf. Lc 2.52). É interessante observar que a situação de emprego "do lar" - usualmente a ocupação da mulher no contexto da economia familiar - manifesta um índice alto de aceitação comparado às respostas dos que indicaram estar "empregados". 


\section{Considerações finais}

O planejamento familiar sugere em sua pauta o acolhimento feliz do filho. Quando é fruto de um planejamento responsável, o processo de parentalidade, no que tange ao cuidado e acolhida do filho, acontece de forma natural. Parece ainda ser razoável afirmar e demonstrar que um planejamento familiar acontecido no seio de uma família, cujo filho é expressão do amor conjugal, supera uma simples e tecnicista regulação da natalidade.

A posição da Igreja Católica, também encontrada em outras igrejas cristãs, não determina o número ideal de filhos que um casal deve gerar, mas aconselha que se acolham a todos como dádivas divinas, assim como os servos receberam os talentos do seu patrão (cf. Mt 25.14-30). Aliás, desde São João Crisóstomo (+407) a teologia cristã ensina que os filhos não devem ser frutos de atos impensados e inconsequentes. Em outros termos, do casal humano se exige uma paternidade responsável ou planejamento familiar.

Os dados acima, da pesquisa realizada em 2014 na referida diocese brasileira, apontam para a expressiva presença do clima de alegria que permeia o anúncio da gravidez do primeiro filho. As marcantes percentagens de alegria, no entanto, não escondem a realidade quanto às reações marcadas pela preocupação, surpresa e aceitação. Seja como for, os apontamentos acima precisam ser comparados com outros ambientes ou regiões, pois várias questões locais podem interferir nos resultados.

Talvez se confirme que em nossa sociedade a realidade do planejamento familiar se dá, na maioria das vezes, de forma implícita e é pensado efetivamente apenas depois do primeiro ou segundo filho. Quando se fala em planejamento familiar implícito, pensa-se naquelas situações em que os filhos são aguardados e se inserem nas condições mais amplas do casal e nos seus projetos de vida. Por exemplo, pessoas casadas que constituem famílias, que não planejam explicitamente ter os filhos em um ou outro determinado momento, mas que os acolhem no contexto familiar. Esse tem sido o modo de a parentalidade suceder na maioria dos casos, criando condições, muitas vezes ótimas, para que ela simplesmente ocorra.

Em suma, o acolhimento do filho tanto nas discussões teóricas como nos dados levantados pela pesquisa de campo evidencia que o mesmo está radicado numa compreensão profunda da vida e de seu significado. À medida que cresce a consciência da necessidade de uma parentalidade responsável, mais nos aproximamos do ideal: que cada criança seja de fato desejada antes mesmo de ter sido concebida. ${ }^{28}$

${ }^{28}$ BEÑERAF, Luiz Féder. Los orígenes de la violencia y la segunda revolución en psicoanálisis: la preconceptologia y la prevención e da violencia. In: SOLÍS-PONTÓN, Leticia; BECERA, Teresa Lartigue; MALDONADO DURÁN, Martin. La cultura de la parentalidad - antídoto contra la violencia y la barbarie. México; Bogotá: Manual Moderno, 2006. p. 58. 


\section{Referências}

BEÑERAF, Luiz Féder. Los orígenes de la violencia y la segunda revolución en psicoanálisis: la preconceptologia y la prevención y de la violencia. In: SOLÍS-PONTÓN, Leticia; BECERA, Teresa Lartigue; MALDONADO DURÁN, Martin. La cultura de la parentalidad - antídoto contra la violencia y la barbarie. México; Bogotá: Manual Moderno, 2006.

BOTERO, Sílvio. O amor conjugal: fundamento do casal humano. Trad. Ivo Montanhese. Aparecida: Santuário, 2001.

CATECISMO DA IGREJA CATÓLICA. Petrópolis: Vozes; São Paulo: Loyola, 2000. CÓDIGO DE DIREITO CANÔNICO. 15. ed. Trad. CNBB. São Paulo: Loyola, 2002.

CONCÍLIO VATICANO II. Constituição Pastoral Gaudium et Spes. 28. ed. Petrópolis: Vozes, 2000. CONSELHO PONTIFÍCIO PARAA FAMÍLIA. Família, Matrimônio e "Uniões de Fato”. 3. ed. São Paulo: Paulinas, 2004.

EGUREN, J. A. Paternidad responsable y valores humanos: aportación al diálogo sobre la planificación familiar. Valencia: Edicep, 1976.

GHIRLANDA, Gianfranco. O Direito na Igreja: Mistério de Comunhão - compêndio de Direito Eclesial. Trad. Roque Frangiotti, Edwino Aloysius Royer, Adauri Fiorotti. Aparecida: Santuário, 2003.

HÄRING, Bernhard. Matrimônio em nosso tempo. Trad. José Antônio G. da Silva Marques. São Paulo: Herder, 1965. . Paternidad responsable. Madrid: Paulinas, 1971.

HORTELANO, Antonio. El amor y la familia en las nuevas perspectivas cristianas. Salamanca: Sígueme, 1974.

IBGE. Pesquisa Nacional por amostra de Domicílios (Pnad) 2006. Disponível em: <http: // www. ibge.gov.br/home/presidencia/noticias>. Acesso em: 18 mar. 2014.

MOSER, Antônio. A paternidade responsável face a uma mentalidade contraceptiva. 3. ed. Petrópolis: Vozes, 1982.

. Planejamento familiar atual na Igreja Católica: do ruído estrondoso a um silêncio perturbador. In: SANCHES, Mário Antônio (Org.). Bioética e planejamento familiar: perspectivas e escolhas. Petrópolis: Vozes, 2014. p. 59-70.

PAULO VI. Carta Encíclica Humanae Vitae. 12. ed. São Paulo: Paulinas, 2010.

RICCI, Luiz Antonio Lopes. Planejamento familiar à luz da ética teológica. In: SANCHES, Mário Antônio (Org.). Bioética e planejamento familiar: perspectivas e escolhas. Petrópolis: Vozes, 2014.

SANCHES, Mário Antônio; et al. Planejamento da Parentalidade no contexto da bioética: busca de uma nova abordagem para pesquisa. Ed. Universitária Champagnat, PUCPR. Curitiba, PR, 2015.

SCHILLEBEECKX, Edward. El Matrimonio: realidad terrena y misterio de salvación. Salamanca: Sígueme, 1968.

WOJTYLA, Karol. Amor e Responsabilidade: estudo ético. Trad. João Jarski e Lino Carrera. São Paulo: Loyola, 1982. 